University of Nebraska - Lincoln

DigitalCommons@University of Nebraska - Lincoln

Biological Systems Engineering: Papers and

Publications

Biological Systems Engineering

6-12-2004

\title{
On-the-go soil sensors for precision agriculture
}

Viacheslav I. Adamchuk

University of Nebraska-Lincoln, viacheslav.adamchuk@mcgill.ca

J. W. Hummel

Cropping Systems and Water Quality Research Unit, USDA Agricultural Research Service, Columbia, MO

M. T. Morgan

Purdue University

S. K. Upadhyaya

University of California-Davis

Follow this and additional works at: https://digitalcommons.unl.edu/biosysengfacpub

Part of the Biological Engineering Commons

Adamchuk, Viacheslav I.; Hummel, J. W.; Morgan, M. T.; and Upadhyaya, S. K., "On-the-go soil sensors for precision agriculture" (2004). Biological Systems Engineering: Papers and Publications. 1.

https://digitalcommons.unl.edu/biosysengfacpub/1

This Article is brought to you for free and open access by the Biological Systems Engineering at DigitalCommons@University of Nebraska - Lincoln. It has been accepted for inclusion in Biological Systems Engineering: Papers and Publications by an authorized administrator of DigitalCommons@University of Nebraska Lincoln. 


\title{
On-the-go soil sensors for precision agriculture
}

\author{
V.I. Adamchuk ${ }^{\mathrm{a}, *}$, J.W. Hummel ${ }^{\mathrm{b}}$, \\ M.T. Morgan ${ }^{\text {c }}$, S.K. Upadhyaya ${ }^{\mathrm{d}}$ \\ a Biological Systems Engineering Department, University of Nebraska-Lincoln, Lincoln, NE 68583, USA \\ ${ }^{\mathrm{b}}$ Cropping Systems and Water Quality Research Unit, USDA Agricultural Research Service, \\ Columbia, MO 65211, USA \\ ${ }^{\mathrm{c}}$ Food Science Department, Purdue University, West Lafayette, IN 47907, USA \\ d Biological and Agricultural Engineering Department, University of California-Davis, Davis, CA 95616, USA
}

Received 24 September 2003; received in revised form 5 January 2004; accepted 8 March 2004

\begin{abstract}
The basic objectives of site-specific management of agricultural inputs are to increase profitability of crop production, improve product quality, and protect the environment. Information about the variability of different soil attributes within a field is essential for the decision-making process. The inability to obtain soil characteristics rapidly and inexpensively remains one of the biggest limitations of precision agriculture. Numerous researchers and manufacturers have attempted to develop on-the-go soil sensors to measure mechanical, physical and chemical soil properties. The sensors have been based on electrical and electromagnetic, optical and radiometric, mechanical, acoustic, pneumatic, and electrochemical measurement concepts. While only electric and electromagnetic sensors are widely used at this time, other technologies presented in this review may also be suitable to improve the quality of soil-related information in the near future.
\end{abstract}

(c) 2004 Elsevier B.V. All rights reserved.

Keywords: Precision agriculture; Soil sensors; Mapping soil properties

\section{Introduction}

Soil testing results are important inputs to the profitable application of fertilizer, lime, and other soil amendments. When soil test results are combined with information about the nutrients that are available to the various crops, a reliable basis for planning the fertility

\footnotetext{
* Corresponding author. Tel.: +1-402-472-8431; fax: +1-402-472-6338.

E-mail address: vadamchuk2@unl.edu (V.I. Adamchuk).
} 
program can be established (Hoeft et al., 1996). An appropriate test may be based on local soil and crop conditions as well as personal preference. A standard test usually includes determination of available phosphorus $(\mathrm{P})$, exchangeable potassium $(\mathrm{K})$, calcium $(\mathrm{Ca})$, and magnesium $(\mathrm{Mg})$, their saturation percentages, the cation exchange capacity (CEC), $\mathrm{pH}$, and lime requirement. Some laboratories may also test for organic matter (OM) content, salinity, nitrate, sulfate, certain micronutrients, and heavy metals (Foth and Ellis, 1988). In addition, the crop growth environment is affected by soil texture (sand, silt and clay content), level of soil compaction, moisture content, and other mechanical and physical soil properties.

One of the most critical aspects of soil testing is actually obtaining representative soil samples (i.e. collected with adequate spatial density at the proper depth and during the appropriate time). Practical advice related to the collecting and handling of soil samples was given by Vitosh et al. (1995), Hoeft et al. (1996), and Gelderman and Mallarino (1998). However, the location and number of soil samples depends on the approach used to manage soil fertility (Havlin et al., 1999). Currently, random, adaptive, and grid sampling techniques are often used. In random sampling, soil cores are obtained from random locations within the field. In adaptive sampling, selected locations depend on prior information. Grid sampling, on the other hand, involves systematically collecting samples from predetermined points in the field. None of the existing soil sampling practices has been recognized as the most effective (Wollenhaupt et al., 1997).

Numerous attempts to develop on-the-go soil sensors have been previously reported and reviewed (Hummel et al., 1996; Sudduth et al., 1997). The development of sensors is expected to increase the effectiveness of precision agriculture (Pierce and Nowak, 1999). In particular, sensors developed for on-the-go measurement of soil properties have the potential to provide benefits from the increased density of measurements at a relatively low cost (Sonka et al., 1997). Although only a few soil sensors are commercially available, there is an on-going effort to develop new prototypes. The purpose of this publication is to review recently reported concepts for on-the-go measurement of soil mechanical, physical and chemical characteristics, and to discuss potential applications of such measurement methods.

\section{Instrumentation and methods}

The global positioning system (GPS) receivers, used to locate and navigate agricultural vehicles within a field, have become the most common sensor in precision agriculture. In addition to having the capability to determine geographic coordinates (latitude and longitude), high-accuracy GPS receivers allow measurement of altitude (elevation) and the data can be used to calculate slope, aspect and other parameters relevant to the landscape.

When a GPS receiver and a data logger are used to record the position of each soil sample or measurement, a map can be generated and processed along with other layers of spatially variable information. This method is frequently called a "map-based" approach. On the other hand, some soil sensors may be used to vary application rates in response to sensor output in real time without a GPS receiver (Morgan and Ess, 1997). Therefore, on-the-go soil sensors can be a part of either "map-based" or "real-time" systems. 
Although there are a large variety of design concepts, most on-the-go soil sensors described in the literature involve one of the following measurement methods:

- Electrical and electromagnetic sensors measure electrical resistivity/conductivity, capacitance or inductance affected by the composition of tested soil.

- Optical and radiometric sensors use electromagnetic waves to detect the level of energy absorbed/reflected by soil particles.

- Mechanical sensors measure forces resulting from a tool engaged with the soil.

- Acoustic sensors quantify the sound produced by a tool interacting with the soil.

- Pneumatic sensors assess the ability to inject air into the soil.

- Electrochemical sensors use ion-selective membranes that produce a voltage output in response to the activity of selected ions $\left(\mathrm{H}^{+}, \mathrm{K}^{+}, \mathrm{NO}_{3}{ }^{-}, \mathrm{Na}^{+}\right.$, etc.).

The majority of sensors described in this review provide signal output that is affected by more than one agronomic soil characteristic. Table 1 lists soil properties that have been targeted using each measurement concept. In many instances, an acceptable correlation between sensor output and a particular agronomic soil property was found for a specific soil type or when the variation of interfering properties was negligibly small. At this time, it remains unknown which sensor combinations could be used to simultaneously describe spatial variation of several agronomic soil properties in diverse crop growth conditions.

The cited studies reported different levels of results on specific sensor development: from theoretical studies to field evaluations of commercial implements. Precision and accuracy have been used as the main quantitative assessments of sensor performance (Vaughan, 1999). Precision usually refers to the ability of the sensor to repeat its own measurement in the same location and time, while accuracy is a measure of how well the sensor measurements correlate to an actual soil property that is determined using the conventional (reference) measurement technique. Both precision and accuracy define how well given soil properties can be predicted based on sensor output. However, the majority of studies report correlations between sensor outputs and conventional measurements expressed either as Pearson coefficient of correlation $(r)$ or coefficient of determination $\left(r^{2}\right)$. It is necessary to keep in mind that both values depend on the range of soil properties used during evaluation and may vary in different fields. Few studies reported actual prediction results using an independent set of data.

\subsection{Electrical and electromagnetic sensors}

Various measurement systems are based on electrical circuits and used to determine the ability of certain media to conduct or accumulate electrical charge. If soil is used as such a medium, its physical and chemical characteristics can affect circuit behavior and, thus, the measured electric parameters. Rapid response, low cost and high durability have made electrical and electromagnetic sensors the most attainable techniques for on-the-go soil mapping. Obtained maps have been correlated to: soil texture, salinity, organic matter, moisture content, and other soil attributes.

The ability of soil to conduct electricity is usually quantified by electrical resistivity (ER) or electrical conductivity (EC). Both values are related to voltage and electric current ratio for a known configuration of transmitting and receiving electrodes. In the case of 
Table 1

Soil properties that have been targeted with various on-the-go soil sensing methods

\begin{tabular}{|c|c|c|c|c|c|c|c|c|c|c|}
\hline \multirow[t]{2}{*}{ Sensors } & \multicolumn{10}{|c|}{ Agronomic soil properties } \\
\hline & $\begin{array}{l}\text { Soil } \\
\text { texture } \\
\text { (clay, silt } \\
\text { and sand } \\
\text { content) }\end{array}$ & $\begin{array}{l}\text { Soil } \\
\text { organic } \\
\text { matter or } \\
\text { total } \\
\text { carbon } \\
\text { content }\end{array}$ & $\begin{array}{l}\text { Soil } \\
\text { moisture } \\
\text { content }\end{array}$ & $\begin{array}{l}\text { Soil } \\
\text { salinity or } \\
\text { sodium } \\
\text { content }\end{array}$ & $\begin{array}{l}\text { Soil com- } \\
\text { paction or } \\
\text { bulk } \\
\text { density }\end{array}$ & $\begin{array}{l}\text { Depth } \\
\text { variability } \\
\text { (depth of } \\
\text { topsoil or } \\
\text { hard pan } \\
\text { detection) }\end{array}$ & Soil pH & $\begin{array}{l}\text { Residual } \\
\text { nitrate or } \\
\text { total } \\
\text { nitrogen } \\
\text { content }\end{array}$ & $\begin{array}{l}\text { Other } \\
\text { macronu- } \\
\text { trients (i.e. } \\
\text { potassium } \\
\text { content) }\end{array}$ & $\begin{array}{l}\text { Cation } \\
\text { exchange } \\
\text { capacity } \\
\text { and other } \\
\text { buffer } \\
\text { indicators }\end{array}$ \\
\hline $\begin{array}{l}\text { Electrical and } \\
\text { electromagnetic }\end{array}$ & $\mathrm{X}$ & $\mathrm{X}$ & $\mathrm{X}$ & $\mathrm{X}$ & & $\mathrm{X}$ & & $\mathrm{X}$ & & $\mathrm{X}$ \\
\hline $\begin{array}{l}\text { Optical and } \\
\text { radiometric }\end{array}$ & $X$ & $\mathrm{X}$ & $\mathrm{X}$ & & & & $\mathrm{X}$ & $\mathrm{X}$ & & $X$ \\
\hline Mechanical & & & & & $\mathrm{X}$ & $\mathrm{X}$ & & & & \\
\hline $\begin{array}{r}\text { Acoustic and } \\
\text { pneumatic }\end{array}$ & $\mathrm{X}$ & & & & $\mathrm{X}$ & $\mathrm{X}$ & & & & \\
\hline Electrochemical & & & & $\mathrm{X}$ & & & $\mathrm{X}$ & $\mathrm{X}$ & $\mathrm{X}$ & \\
\hline
\end{tabular}


direct measurement of electrical resistivity/conductivity, such electrodes can be as simple as isolated coulters that are rolled through the field. The distance between electrodes defines the effective measurement depth. Therefore, multiple depths can be sensed simultaneously if more than two electrodes are used.

On the other hand, non-contact EC measurement can be accomplished using a pair of inductors. When a transmitting coil with alternating current is placed in proximity to the soil, the magnetic field induces a flow of electrical charge in the soil. This current is sensed using a receiving coil also placed in proximity to the soil. The distance between two coils and their orientation defines the effective measurement depth.

Several commercial implements have been developed and marketed that utilize one of these methods for on-the-go measurement of electrical resistivity/conductivity. Buchleiter and Farahani (2002), Fritz et al. (1999), and Sudduth et al. (2003) compared electromagnetic induction and contact sensors while mapping agricultural fields. They reported similarities in map patterns and high correlation between collocated points (Pearson coefficient of correlation as high as 0.92). Although multiple electrical conductivity maps developed from data collected in the same field may repeat in terms of pattern, significant differences are often present when comparing collocated points. Operation speed and height, soil moisture and temperature, topsoil depth, and simply instrumentation drift with time may cause significant effects on EC measurements while using an electromagnetic sensor (Sudduth et al., 2001).

Because a soil profile is seldom a homogeneous substance, values of electrical resistivity/conductivity measured at the surface represent the apparent physical characteristics of a homogeneous medium with similar dimensions as the soil being tested. Therefore, many different soil profiles may produce similar measurements of the apparent electrical resistivity/conductivity (Dabas and Tabbagh, 2003). Consequently, measured values of electrical resistivity/conductivity reveal the heterogeneity of soil present in a single agricultural field and are affected by more than one important physical soil characteristic: soil texture, salinity, organic matter, moisture content, and the depth of the clay pan (Mueller et al., 2003). Secondary correlation with soil nutrients and $\mathrm{pH}$ has been observed in some studies. Lund et al. (1999) as well as Colburn (1999) described potential usages of electrical conductivity measurements for site-specific management.

Since a single measurement is theoretically insufficient to predict several soil properties at the same time, it is reasonable to explore the possibility of multiple measurements. Fan et al. (2001) have attempted to simultaneously measure soil conductive and capacitive properties. They found through laboratory testing that there is a potential for separating soil moisture and soil salinity if a frequency response analysis is applied $\left(r^{2}=0.73\right.$ and 0.56 , respectively). Lee et al. (2002) used a similar method under controlled soil density and depth conditions and obtained $r^{2}$ values of 0.88 and 0.83 for soil moisture and soil salinity, respectively.

The fact that the dielectric constant of water is an order of magnitude greater than that of soil makes measurement of capacitance or dielectric constant a very attractive technique to determine soil moisture content (Starr and Paltineanu, 2002). Whalley et al. (1992), for example, designed a tine-shaped sensor for on-the-go measurement of soil moisture. They reported that $84 \%$ of sensor variance could be explained through differences in moisture content, while dry bulk density also had a significant effect on the measurements obtained.

Liu et al. (1996) incorporated a dielectric-based soil moisture sensor into an instrumented chisel and conducted field tests to determine if the system worked satisfactorily under 
dynamic field conditions. They located the moisture sensor in an insulated nylon block, away from any metal, directly behind the cutting edge of a soil mechanical resistance-mapping sensor. Field tests revealed that this was a viable technique to rapidly measure soil moisture content in situ, although interference from soil salinity, temperature, and perhaps soil texture affected the moisture measurement. Andrade et al. (2001a) further improved this sensor to overcome the interference. Although no significant effect of soil texture was detected in their study, the interference of temperature and salinity was significant. This interference was overcome through real-time measurement of temperature as well as the amplitude and frequency at resonance, and application of empirically defined relationships. Sensor evaluation revealed an acceptable correlation with volumetric moisture content $\left(r^{2}\right.$ value was 0.87 and 0.78 during laboratory and field tests, respectively).

Table 2 summarizes the electrical and electromagnetic sensors described above. It appears that both conductive and capacitive soil properties that can be measured on-the-go are affected by several agronomic soil characteristics. It was observed that soil types (mainly soil texture) significantly affect the output of most commercially available electrical resistivity/conductivity sensors. Field variability of soil salinity, moisture and other characteristics interferes with this relationship. Capacitor-type sensors have been useful in determining volumetric moisture content in combination with the mechanical sensors described later.

\subsection{Optical and radiometric sensors}

Measurement of reflectance, absorption or transmittance characteristics of a material provides a non-destructive and rapid technique to evaluate its properties. Determination of

Table 2

Electrical and electromagnetic sensors

\begin{tabular}{|c|c|c|c|}
\hline Sensor concept & Status of development & Current results & Key references \\
\hline $\begin{array}{l}\text { Electrical conductivity/ } \\
\text { resistivity contact } \\
\text { sensors (rolling } \\
\text { coulters/spike } \\
\text { wheels) }\end{array}$ & $\begin{array}{l}\text { Three different sets of } \\
\text { commercial } \\
\text { implements, numerous } \\
\text { agronomic research } \\
\text { projects }\end{array}$ & $\begin{array}{l}\text { Stable field pattern, soil } \\
\text { types (texture) seem to } \\
\text { be revealed the best, } \\
\text { indirect prediction of } \\
\text { soil nitrate content, } \\
\text { effects of organic } \\
\text { matter, moisture, and } \\
\text { salinity }\end{array}$ & $\begin{array}{l}\text { Lund et al. (1999), } \\
\text { Colburn (1999), Dabas } \\
\text { and Tabbagh (2003) }\end{array}$ \\
\hline $\begin{array}{l}\text { Electrical conductivity } \\
\text { proximity sensors } \\
\text { (electromagnetic } \\
\text { induction method) }\end{array}$ & $\begin{array}{l}\text { Commercial } \\
\text { implements, numerous } \\
\text { agronomic research } \\
\text { projects }\end{array}$ & $\begin{array}{l}\text { Stable field pattern, } \\
\text { highly correlated to } \\
\text { contact sensors, } \\
\text { additional effects of } \\
\text { operation speed and } \\
\text { height }\end{array}$ & Sudduth et al. (2001) \\
\hline $\begin{array}{l}\text { Electrical conductivity } \\
\text { and capacitance } \\
\text { contact sensor } \\
\text { (rolling electrodes) }\end{array}$ & $\begin{array}{l}\text { Laboratory tests, } \\
\text { controlled conditions }\end{array}$ & $\begin{array}{l}\text { Simultaneous } \\
\text { measurement of soil } \\
\text { moisture and salinity }\end{array}$ & Lee et al. (2002) \\
\hline $\begin{array}{l}\text { Capacitance contact } \\
\text { sensor (drag type) }\end{array}$ & $\begin{array}{l}\text { Field tests, commercial } \\
\text { circuits are available }\end{array}$ & $\begin{array}{l}\text { Correlation with } \\
\text { volumetric moisture } \\
\text { content }\end{array}$ & Andrade et al. (2001a) \\
\hline
\end{tabular}


the amount of energy reflected from the soil surface in a particular spectral range is the most popular approach in agriculture. Similar to electrical and electromagnetic sensors, optical and radiometric measurements are frequently affected by a combination of soil attributes. However, the response in different parts of the spectral range may be affected by various soil properties to different degrees, which provides an opportunity to separate several effects with a single sensor response. According to Baumgardner et al. (1985), moisture, organic matter, particle size, iron oxides, mineral composition, soluble salts, parent material, and other attributes affect soil reflectance.

Historically, soil color (reflectance in the visual portion of the spectra) has been one of the most obvious parameters used to characterize heterogeneity of soil in a given agricultural field. Aerial and satellite imagery obtained using remote sensing techniques (Frazier et al., 1997 ) is an excellent means of analyzing the variability of soil reflectance at the landscape level. Such data are usually referred to as "bare soil images". However, crop residue cover, as well as the other limitations of remote sensing, limits the use of aerial and satellite bare soil imagery. On the other hand, on-the-go sensors that operate beneath the soil surface are not affected by weather and field surface conditions.

Early laboratory studies (e.g., Krishnan et al., 1980; Stoner and Baumgardner, 1981) have shown correlation of soil OM with both visible and near infrared (NIR) reflectance. Shonk et al. (1991) developed a shank-mounted sensor that measured soil reflectance at $660 \mathrm{~nm}$ and correlated these measurements with organic matter (for moist soil $r^{2}=0.71$ ). This "organic matter sensor" has been used to control soil-applied herbicide rates in real-time based on the variability of OM. The need for soil-specific calibration of the sensor was the main limitation to more widespread use of this sensor.

Later laboratory tests have shown that NIR soil reflectance can be used to estimate soil OM, soil moisture, and CEC in soils from a wide geographic area of the US Corn Belt and for both surface and subsurface soils (Sudduth and Hummel, 1996; Hummel et al., 2001). During another laboratory study, Viscarra Rossel and McBratney (1998) determined that NIR reflectance could predict clay and moisture content, but not OM. Reeves et al. (2002) conducted laboratory tests and concluded that both near- and mid-infrared spectroscopy have great potential for organic carbon determination. Similarly, Fystro (2002) reported the potential for using visible and NIR spectroscopy to predict both organic carbon $\left(r^{2}=0.65\right)$ and total nitrogen $\left(r^{2}=0.87\right)$. Lee et al. (2001) indicated that calcium and magnesium content could be predicted when spectral responses of the soil samples were analyzed.

Sudduth and Hummel (1993a) developed a portable, on-the-go spectrophotometer designed to acquire NIR soil reflectance data at a number of narrow-band wavelengths, and successfully predicted soil organic carbon across a range of soil types and moisture contents with standard error of prediction (SEP) equal to $0.23 \%$. In field tests, the movement of soil past the sensor during scanning introduced errors and increased the SEP for organic carbon prediction to $0.53 \%$ (Sudduth and Hummel, 1993b). Shibusawa et al. (1999) reported on a real-time portable spectrophotometer that is capable of field mapping of soil properties using soil reflectance data from 400 to $2400 \mathrm{~nm}$. They correlated spectral reflectance data at four single wavelengths to soil moisture, $\mathrm{pH}, \mathrm{EC}$, and soil $\mathrm{OM}\left(r^{2}\right.$ values were 0.68 , $0.61,0.64$, and 0.87 , respectively). However, a multispectral approach was required to correlate NIR reflectance and soil nitrate nitrogen levels $\left(r^{2}=0.5\right)$. A later version of this system incorporated a spectrophotometer with a digital video camera, EC electrodes and a 
mechanical load sensor, and was used to study both spatial and temporal variability of soil $\mathrm{OM}$ and nitrate content (Shibusawa et al., 2003).

Christy et al. (2003) reported on a prototype soil reflectance mapping unit equipped with a near infrared spectrophotometer. Results of a pilot study indicated that locally weighted principal component regression analysis $(900-1700 \mathrm{~nm})$ was capable of predicting moisture, total carbon, total nitrogen, and $\mathrm{pH}\left(r^{2}=0.82,0.87,0.86\right.$, and 0.72 , respectively) using data from a single field in central Iowa. The unit produced data with a high level of repeatability between travel passes that resulted in clear definition of soil patterns related to the spectral reflectance.

Based on the preliminary work conducted by Upadhyaya et al. (1993), Ehsani et al. (1999) studied the possibility of using near infrared spectroscopy for rapid determination of soil nitrate content. They conducted laboratory and field experiments using two soil types to investigate the suitability of NIR spectroscopy for measuring soil nitrate content. Their results showed that it was possible to use the NIR spectrum of the soil in the range of $1800-2300 \mathrm{~nm}$ to determine soil nitrate content, but a site-specific calibration was necessary to map nitrate variation over a large area. To overcome the problem of non-uniqueness of the calibration curve, Ehsani et al. (2000) used mid-infrared (MIR) spectroscopy to reveal the nitrate ion signature that was not detected in the NIR range. Their preliminary studies clearly identified a prominent nitrate peak located at $7194 \mathrm{~nm}$. However, several physical properties significantly influenced the MIR spectra. To overcome this problem, the investigators used one-dimensional continuous wavelet decomposition and calculated the ratio of volume under the nitrate peak to the volume under the water peak $(6061 \mathrm{~nm})$. The MIR spectra results were compared to soil nitrate content over a range of nitrate concentrations from 400 to $3000 \mathrm{mg} / \mathrm{kg}$ of nitrate-nitrogen $\left(r^{2}=0.88\right)$. Based on this laboratory study, which included two soil types and two sources of mineral nitrogen added as a fertilizer, they concluded that MIR spectroscopy provides a viable technique to rapidly determine soil mineral nitrogen.

Other radiometric sensors, in addition to optical reflectance devices, have also been developed. Whalley and Bull (1991) theoretically examined the feasibility of using a microwave sensor to predict soil moisture content. They reported potential difficulties with sensor calibration and measurements below $10 \mathrm{~cm}$.

Ground penetrating radar (GPR) is another sensor that is similar in principle to seismic and sonar methods. GPR usually consists of two antennas: a transmitter radiates pulses of high-frequency electromagnetic waves, and a receiver detects the reflected electromagnetic waves as a function of time (Davis and Annan, 2002). GPR has the potential to help map soil properties such as soil texture and organic matter, thickness and depth of soil horizons and water tables, and differences in soil compaction due to plow pan development (Johnson et al., 1982; Truman et al., 1988; Doolittle and Collins, 1995; Freeland et al., 1998). Application of GPR traditionally requires visual inspection of the site and interpretation of the radargram regions into classes, followed by ground-truthing for verification. Newer systems can perform some of these procedures automatically. If a quantitative procedure for systematic classification can be developed, GPR has the potential for broad use in precision agriculture as a non-invasive technique to delineate subsurface features.

To accomplish on-the-go mapping, commercial GPR systems have been mounted on mobile platforms. Original studies were conducted using linear distance markers, which 
required substantial time. Freeland et al. (2002) linked geographic information system (GIS) and GPS packages with GPR to increase data collection and image post-processing efficiency. Odhiambo et al. (2002) showed that fuzzy-neural networks could be applied to GPR data to supply real-time soil profile clustering and classification during soil surveys. Huisman et al. (2003) has mentioned a GPR mounted on a mobile platform to provide on-the-go estimates of volumetric soil moisture content. Other applications of on-the-go GPR measurements may be attempted in the future.

Optical soil sensors appear to have great potential for determining soil organic matter content. Essentially, they measure soil color that was historically used to assess soil carbon. On the other hand, hyperspectral soil reflectance measurements do not differ from the data obtained from aerial or satellite platforms of remote sensing, and the majority of data processing algorithms remain applicable. In studies related to soil optical properties, it has been proven that visual and NIR soil spectral response can predict texture, moisture, CEC and other soil amendments if proper data analysis techniques are applied (Table 3). In addition, several researchers have successfully correlated soil reflectance with soil chemical properties (i.e. soil nitrate content and $\mathrm{pH}$ ). Providing reliable and inexpensive acquisition of subsurface soil reflectance measurements has been one of the major limitations in the past.

GPR represents another radiometric method that has great potential in geophysics in general and agriculture in particular, especially to support water management. Davis and Annan (2002) suggest that GPR instrumentation and methodology are just maturing. The

Table 3

Optical and radiometric sensors

\begin{tabular}{|c|c|c|c|}
\hline Sensor concept & Status of development & Current results & Key references \\
\hline $\begin{array}{l}\text { Single wavelength } \\
\text { subsurface soil } \\
\text { reflectance sensor }\end{array}$ & Field tests & $\begin{array}{l}\text { Correlation with organic } \\
\text { matter for the same soil } \\
\text { type interference of soil } \\
\text { moisture }\end{array}$ & Shonk et al. (1991) \\
\hline $\begin{array}{l}\text { Hyperspectral visual } \\
\text { and near-infrared } \\
\text { subsurface soil } \\
\text { reflectance sensor }\end{array}$ & $\begin{array}{l}\text { Extensive laboratory } \\
\text { studies, field tests, } \\
\text { commercial } \\
\text { spectrometers, various } \\
\text { data processing } \\
\text { algorithms }\end{array}$ & $\begin{array}{l}\text { Organic matter (carbon } \\
\text { content), soil texture, } \\
\text { moisture and CEC were } \\
\text { primary targets, some } \\
\text { reports on correlations } \\
\text { with electrical } \\
\text { conductivity, soil pH } \\
\text { and nutrients }\end{array}$ & $\begin{array}{l}\text { Shibusawa et al. (1999), } \\
\text { Hummel et al. (2001), } \\
\text { Christy et al. (2003) }\end{array}$ \\
\hline $\begin{array}{l}\text { Hyperspectral visual } \\
\text { and mid-infrared } \\
\text { subsurface soil } \\
\text { reflectance sensor }\end{array}$ & Laboratory tests & $\begin{array}{l}\text { Correlation with soil } \\
\text { mineral nitrogen }\end{array}$ & Ehsani et al. (2000) \\
\hline Microwave sensor & Theoretical study & $\begin{array}{l}\text { Correlation with soil } \\
\text { moisture }\end{array}$ & $\begin{array}{l}\text { Whalley and Bull } \\
\text { (1991) }\end{array}$ \\
\hline $\begin{array}{l}\text { Ground penetrating } \\
\text { radar }\end{array}$ & $\begin{array}{l}\text { Field tests, commercial } \\
\text { instruments available }\end{array}$ & $\begin{array}{l}\text { Correlation with } \\
\text { volumetric soil } \\
\text { moisture, studies on } \\
\text { geophysical soil } \\
\text { composition }\end{array}$ & Huisman et al. (2003) \\
\hline
\end{tabular}


introduction of compact and readily portable systems along with digital data acquisition facilitates collection of geo-referenced data as well as the incorporation of modern data analysis techniques, such as neural networks (Odhiambo et al., 2002). These developments, and the relatively low cost of current systems, should result initially in increased research on the applicability of GPR to precision agriculture, and ultimately, increased adoption of commercially available GPR systems.

\subsection{Mechanical sensors}

Electrical, electromagnetic, optical and radiometric soil sensors provide capability to evaluate variability of soil physical composition while traveling across the field. However, a mechanical characteristic of soil such as soil strength (usually assessed through measuring mechanical resistance) may provide additional useful information about soil conditions (e.g., compaction). Regions of high mechanical resistance in the soil may arise naturally, be caused by compaction from heavy farm machinery, or by the formation of plow pans. In each case, soil particles are positioned closer to each other, and the process is referred to as compaction. Compacted soils reduce growth rates of crop roots and thus limit the availability of water and nutrients to the plant (Upadhyaya et al., 1999).

A standard vertical cone penetrometer is frequently used to measure soil resistance to penetration (ASAE, 2002), which is believed to be a representation of soil compaction. Even when automated, cone penetrometer measurements are typically time consuming and the results are highly variable. To overcome these problems, a number of prototype systems have been developed for on-the-go sensing of soil mechanical resistance.

Strain gauges and load cells provide a very convenient way of measuring forces acting on tillage tools. They are relatively inexpensive, very robust (i.e. can withstand harsh field environments), and are easily interfaced to a data acquisition system, thus making them ideal for real-time applications. Load cells are routinely used to measure draft, vertical load, side force, and moments acting on tillage implements. For example, in a study conducted by Glancey et al. (1996), a tillage implement was calibrated using a three-point hitch dynamometer in different soil conditions and at different speeds.

Alihamsyah et al. (1990) developed a system for mapping soil mechanical resistance using a horizontal cone and wedge penetrometer at a particular depth. The correlation coefficients between horizontal penetrometer measurements and a standard (vertical) penetrometer were between 0.74 and 0.99. An instrumentation system for measuring both horizontal and vertical components of the overall mechanical resistance to a deep tillage implement was designed by Owen et al. (1987). Similarly, Liu et al. (1996) developed a tine instrumented with a load cell to measure soil resistance to cutting. They hypothesized that when an instrumented tine is pulled through the soil at a constant depth and speed, the force required to pull the tine is a function of soil bulk density (compaction), texture, and moisture content. If the soil cutting force is corrected for the moisture content, an index called texture-compaction index (TCI) can be determined. Since soil texture does not change with time, TCI can be used to infer soil compaction level.

In general, any instrumented soil tillage tool can be used to determine spatial variation of draft force. For example, in research conducted by Van Bergeijk and Goense (1996), tillage resistance was measured using a plow. They demonstrated how specific draft maps could be 
used to locate different types of soil within the field. In another study, Ehrhardt et al. (2001) used an electrical conductivity (EC) cart equipped with a load cell as a reference implement to predict draft requirements in different areas of a field. The Pearson correlations between measured draft and predicted draft, while using an EC cart as the reference, were between 0.89 and 0.95 .

Although an index like TCI or soil strength estimated using a "draft cart" can provide information about soil density over the whole cutting depth, they are of little use in locating the presence of a compacted layer within the soil mass. A shank instrumented with an array of strain gauges, such as that developed by Glancey et al. (1989), can be used to measure the soil cutting force profile, and to locate hard pans. Although the design used by these investigators located the hard pan and estimated the force profile, there were some concerns related to sensitivity and drift of the gauges. Another system with an array of strain gauges attached to the backside of a vertical smooth blade has been developed and tested by Adamchuk et al. (2001a). The system was capable of estimating soil mechanical resistance at three depth intervals. In this system, a relatively low signal to noise ratio made it difficult to predict soil mechanical resistance near the surface. Another prototype of the vertical blade equipped with an array of strain gauges was used both to estimate a spatial pattern of soil resistance and to identify the trend of soil resistance change with depth, assuming a linear change of resistance pressure with depth (Adamchuk et al., 2001b).

Andrade et al. (2001b, 2002) developed a compaction profile sensor that used eight independent load cells housed within a shank body to measure soil cutting force acting over eight cutting elements spaced $5 \mathrm{~cm}$ apart. These cutting elements were evenly distributed over an operating depth of $61 \mathrm{~cm}$. Field tests indicated that the soil cutting force predicted from measured cone index values was comparable to the actual soil cutting force measured using the soil compaction profile sensor $\left(r^{2}=0.99\right)$. In addition, the investigators developed a more compact and less expensive sensor that can sense the soil compaction profile to a depth of $46 \mathrm{~cm}$. Chung et al. (2003) and Verschoore et al. (2003) have further explored the idea of using multiple horizontal penetrometers to estimate soil mechanical resistance at 5 and 6 depths, respectively.

Determination of a layer with high compaction has been one of the major objectives for soil mechanical resistance mapping. Stafford and Hendrick (1988) developed an instrumented blade moving in undisturbed soil mounted on the back of a deep tillage tool, and showed it could dynamically determine "soil pans". Manor and Clark (2001) designed an instrumented subsoiler to map "hard-pans" using dynamic operation of the implement. A patent has been recently issued (Raper and Hall, 2003) on a similar sensor that incorporates a horizontal probe with a vertically oscillating action to provide a profile of soil strength. The resulting maps could be used to prescribe variable depth tillage in different field areas. A control system, such as the one developed by Khalilian et al. (2002) can then be used to guide the tillage equipment to the appropriate depth. Adamchuk et al. (2003b) integrated a measurement system with a commercial implement for deep soil tillage. The system is capable of real-time assessment of variation in soil mechanical resistance with depth, and could guide itself to appropriate operating depth.

Maps of soil mechanical resistance or draft of agricultural implements reveal field areas potentially limiting root growth (Table 4). Both soil compaction and low moisture content can theoretically cause high soil strength. Proper timing of soil mapping or integration 
Table 4

Mechanical sensors

\begin{tabular}{|c|c|c|c|}
\hline Sensor concept & Status of development & Current results & Key references \\
\hline Draft force mapping & $\begin{array}{l}\text { Use of commercial } \\
\text { implements, available in } \\
\text { most modern tractors }\end{array}$ & $\begin{array}{l}\text { Relationship to } \\
\text { pre-tillage conditions }\end{array}$ & $\begin{array}{l}\text { Van Bergeijk and } \\
\text { Goense (1996), } \\
\text { Ehrhardt et al. (2001) }\end{array}$ \\
\hline $\begin{array}{r}\text { An implement equipped } \\
\text { with load transducers } \\
\text { to measure total draft }\end{array}$ & $\begin{array}{l}\text { Field tests, mapping of } \\
\text { commercial fields }\end{array}$ & $\begin{array}{l}\text { Correlation with } \\
\text { bulk-density } \\
\text { (compaction) for } \\
\text { specified texture and } \\
\text { moisture }\end{array}$ & $\begin{array}{l}\text { Owen et al. (1987), Lee } \\
\text { et al. (1996) }\end{array}$ \\
\hline $\begin{array}{l}\text { Single depth horizontal } \\
\text { penetrometer }\end{array}$ & Field tests & $\begin{array}{l}\text { Correlation with cone } \\
\text { penetrometer }\end{array}$ & $\begin{array}{l}\text { Alihamsyah et al. } \\
\text { (1990) }\end{array}$ \\
\hline $\begin{array}{l}\text { Vertical blade (tine) } \\
\text { equipped with an } \\
\text { array of strain gauges }\end{array}$ & $\begin{array}{l}\text { Field tests, mapping of } \\
\text { commercial fields }\end{array}$ & $\begin{array}{l}\text { Correlation with vertical } \\
\text { cone penetrometer, } \\
\text { determination of soil } \\
\text { mechanical resistance } \\
\text { variation with depth }\end{array}$ & $\begin{array}{l}\text { Glancey et al. (1989), } \\
\text { Adamchuk et al. } \\
\text { (2001a) }\end{array}$ \\
\hline $\begin{array}{l}\text { Vertical tine equipped } \\
\text { with an array of load } \\
\text { cells and independent } \\
\text { horizontal soil } \\
\text { penetrometers }\end{array}$ & $\begin{array}{l}\text { Field tests, mapping of } \\
\text { commercial fields }\end{array}$ & $\begin{array}{l}\text { Correlation with vertical } \\
\text { cone penetrometer, } \\
\text { determination of soil } \\
\text { mechanical resistance at } \\
\text { several specific depths }\end{array}$ & $\begin{array}{l}\text { Andrade et al. (2002), } \\
\text { Chung et al. (2003), } \\
\text { Verschoore et al. (2003) }\end{array}$ \\
\hline $\begin{array}{l}\text { Measurement } \\
\text { implement with } \\
\text { dynamic depth } \\
\text { operation capability }\end{array}$ & Soil bin and field tests & $\begin{array}{l}\text { Detecting hard (plow) } \\
\text { pans through fluctuating } \\
\text { depth of a tool for } \\
\text { measuring soil } \\
\text { mechanical resistance }\end{array}$ & $\begin{array}{l}\text { Stafford and Hendrick } \\
\text { (1988), Manor and } \\
\text { Clark (2001), Raper and } \\
\text { Hall (2003) }\end{array}$ \\
\hline $\begin{array}{l}\text { Deep tillage implement } \\
\text { equipped with a set } \\
\text { of load cells and } \\
\text { strain gauges }\end{array}$ & Preliminary field tests & $\begin{array}{l}\text { Capability to provide } \\
\text { real-time correction of } \\
\text { tillage depth based on } \\
\text { the variation of soil } \\
\text { mechanical resistance } \\
\text { with depth }\end{array}$ & $\begin{array}{l}\text { Adamchuk et al. } \\
(2003 \mathrm{a}, \mathrm{b})\end{array}$ \\
\hline
\end{tabular}

with a sensor targeting soil moisture may allow delineation of areas recommended for spot (local) tillage. Results of research aimed at assessing the benefits of variable tillage are still limited. Currently, there is no other obvious potential utilization of data collected with any mechanical sensor for crop production. A number of investigations have attempted to search for soil depth where a local maximum of soil mechanical resistance occurred (plow or hard pan). Adjusting tillage depth to remove the hard pan has potential economic impact and may become commercially available soon.

\subsection{Acoustic and pneumatic sensors}

In addition to electrical, electromagnetic, optical, radiometric, and mechanical sensors, several attempts have been made to use alternative means to differentiate mechanical and physical characteristics of soil. Thus, acoustic and pneumatic sensor measurements have been correlated to soil texture and compaction. 
Table 5

Acoustic and pneumatic sensors

\begin{tabular}{|c|c|c|c|}
\hline Sensor concept & Status of development & Current results & Key references \\
\hline $\begin{array}{l}\text { Microphone equipped } \\
\text { soil shank }\end{array}$ & Soil bin tests & $\begin{array}{l}\text { Correlation with soil } \\
\text { clay content (soil types) }\end{array}$ & Liu et al. (1993) \\
\hline $\begin{array}{l}\text { Microphone equipped } \\
\text { horizontal cone } \\
\text { penetrometer }\end{array}$ & Soil bin tests & $\begin{array}{l}\text { Correlation with cone } \\
\text { penetrometer to detect } \\
\text { plow pan depth }\end{array}$ & Tekeste et al. (2002) \\
\hline Air pressure transducer & Field tests & $\begin{array}{l}\text { Separating different } \\
\text { tillage treatments, } \\
\text { affected by } \\
\text { structure/compaction, } \\
\text { moisture and soil type }\end{array}$ & $\begin{array}{l}\text { Clement and } \\
\text { Stombaugh (2000) }\end{array}$ \\
\hline
\end{tabular}

Liu et al. (1993) reported on preliminary tests of an acoustic measurement method for determining soil texture. A shank with a rough surface and hollow cavity was equipped with a microphone that recorded the sound produced through interaction of soil and the shank. The frequency of the resulting sound was used to distinguish among different types of soil. In a system developed by Tekeste et al. (2002), sound waves were used to detect compaction layers. A small microphone installed inside a horizontal cone attached to a tine was pulled through the soil. The amplitude of sound in a selected frequency range was compared to the cone index obtained at different depths of a soil profile. They reported that the instrument could successfully detect a prepared hard pan at a particular depth. In both of these studies it was necessary to account for background noise.

Estimation of soil compaction was attempted by measuring the pressure required to force a given flow of air into the soil (Clement and Stombaugh, 2000). An air injector was placed in direct contact with the soil below the surface. Air pressure and flow were recorded and compared with air permeability. This sensor was capable of detecting changes in soil structure/compaction, moisture content, and soil type. During preliminary field tests, the system was able to differentiate between several tillage treatments. Air permeability was previously related to wheel traffic soil compaction in a study involving several soil types (Wood et al., 1991).

Both acoustic and pneumatic sensors serve as alternatives to mechanical sensors when studying the interaction between soil and an agricultural implement (Table 5). At this time, the relationship between sensor output and the physical state of soil is poorly understood and additional research is needed. Because of conceptually different measurement principles, acoustic and pneumatic sensors may be strong candidates for sensor fusion, in which multiple data streams are merged to improve prediction of targeted soil attributes.

\subsection{Electrochemical sensors}

Most sensors described above have been used to directly or indirectly assess spatial variability of different mechanical and physical soil properties. On the other hand, direct on-the-go measurement of soil chemical characteristics, such as $\mathrm{pH}$ or nutrient content has been the objective of considerable research. Electrochemical methods have been success- 
fully used to directly evaluate soil fertility. This is usually done by either an ion-selective electrode (glass or polymer membrane), or an ion-selective field effect transistor (ISFET). In both cases, measured voltage (potential difference) between sensing and reference parts of the system is related to the concentration of specific ions $\left(\mathrm{H}^{+}, \mathrm{K}^{+}, \mathrm{NO}_{3}{ }^{-}\right.$, etc.). Ion selective electrodes have been historically used by commercial soil laboratories to conduct standard chemical soil tests, and they are widely used to measure soil $\mathrm{pH}$.

Ion-selective field effect transistors have several advantages over ion selective electrodes, such as small dimensions, low output impedance, high signal-to-noise ratio, fast response and the ability to integrate several sensors on a single electronic chip. In a laboratory study, Birrell and Hummel (1997) investigated the use of a multi-ISFET sensor chip to measure soil nitrate in a flow injection analysis (FIA) system using low flow rates, short injection times, and rapid rinsing. The multi-ISFET/FIA system was successfully used to measure soil nitrate content in manually prepared soil extracts $\left(r^{2}>0.90\right)$ under controlled conditions. The rapid response of the system allowed samples to be analyzed within $1.25 \mathrm{~s}$, and the low sample volumes required by the multi-sensor ISFET/FIA system makes it a likely candidate for use in a real-time soil nutrient sensing system. The potential of several polyvinyl chloride (PVC) matrix membranes for use as ISFET membranes for soil nitrate measurement was investigated by Birrell and Hummel (2000). More recently, research on rapid extraction of nitrate (Price et al., 2003) demonstrated that judicious selection of data analysis techniques could provide nitrate measurements in $2-5 \mathrm{~s}$ after injection of the extracting solution into the soil core.

The automation of real-time soil nutrient measurement using ISFET/FIA technology depends on rapid and precise soil sampling and interfacing with the sensor. Birrell and Hummel (2001) tested a prototype mechanical extraction system; however, the extraction system did not consistently provide soil extracts that could be analyzed by the ISFET/FIA system, and required considerable improvement. Yildirim et al. (2003) developed an automated electro-pneumatic soil sampling method, which may be capable of providing soil samples for on-the-go soil analysis. Laboratory tests indicate that the sampling method can rapidly cut and transport soil samples across a range of soil texture and moisture levels while maintaining a consistent sample mass.

Loreto and Morgan (1996) developed another automated system for on-the-go measurement of soil nitrate. The system consisted of a core-sampling wheel, indexing and processing table, and data acquisition and control systems. It was capable of conducting sampling, chemical extraction and measurement of ion concentration with an ISFET in field conditions. In laboratory soil bin tests, correlations of ISFET response to a conventional nitrate electrode and to laboratory colorimetric analysis were 0.65 and 0.43 , respectively. The weakest link in the system was the ISFET's response and calibration drift. Successful attempts were also made to measure soil $\mathrm{pH}$ using the same instrumentation with a $\mathrm{pH}$ electrode.

Adsett et al. (1999) also developed a prototype soil nitrate monitoring system consisting of a soil sampler, a conveying and metering unit, an extraction and measurement unit, and a control unit. Through the analysis of response curves for different soil types, a procedure was developed to predict soil nitrate using an $\mathrm{NO}_{3}{ }^{-}$ion-selective electrode in less than $10 \mathrm{~s}$. While obtaining acceptable results during laboratory testing, field evaluation revealed the need for additional improvement of the sampler and other system components. 
A successful automated system for on-the-go mapping of soil $\mathrm{pH}$ was developed and tested under field conditions by Adamchuk et al. (1999). While traveling across the field, a soil sampling mechanism located in a toolbar-mounted shank scooped a sample of soil from a depth of approximately $10 \mathrm{~cm}$ and brought it into firm contact with the sensitive membranes of two flat-surface ion-selective electrodes. After stabilization of the electrode output (typically 5-15 s), a new soil sample was obtained and the electrode surfaces were rinsed at the same time. This method was referred to by the authors as direct soil measurement (DSM). Every measurement was geo-referenced using a GPS receiver. Collins et al. (2003) modified the soil sampling mechanism by using a horizontal coring tube, which significantly increased the reliability of on-the-go soil $\mathrm{pH}$ mapping. A commercial instrumentation system has recently become available.

An agro-economic analysis by Adamchuk et al. (2004) showed that higher resolution maps could significantly decrease $\mathrm{pH}$ estimation errors and increase potential profitability of variable rate liming. A simulation comparing 1 ha $(2.5$ acre $)$ grid point sampling and automated mapping resulted in US\$ 6.13/ha higher net return over the cost of liming during a four-year growing cycle in a corn-soybean rotation.

The ability to obtain high-resolution maps of soil nitrate and potassium levels at the time of $\mathrm{pH}$ mapping could further expand the potential for economic and environmental benefits of site-specific crop management. Preliminary laboratory evaluation of potassium and nitrate ion-selective electrodes showed that it is feasible to use both $\mathrm{NO}_{3}{ }^{-}$and $\mathrm{K}^{+}$ ion-selective electrodes to determine soluble nitrate and potassium contents on naturally moist soil samples with the same level of errors (less than $0.3 \log \left(\mathrm{K}^{+}\right)$or $\log \left(\mathrm{NO}_{3}{ }^{-}\right)$) as soil pH (Adamchuk et al., 2003a). However, when comparing this error to the total field variability, potassium and nitrate measurements have much lower relative accuracy than soil $\mathrm{pH}$. Therefore, the potential for DSM using ion-selective electrodes appears to decline in the order $\mathrm{pH}>\mathrm{K}^{+}>\mathrm{NO}_{3}{ }^{-}$. Additional research is required to evaluate the application of DSM for mapping soil $\mathrm{pH}$, plant-available $\mathrm{K}^{+}$and $\mathrm{NO}_{3}{ }^{-}$, both in terms of improving sensor performance and interpretation of the results for site-specific management decisions. The major drawback of the proposed methodology is that the values measured on-the-go represent snapshots of $\mathrm{pH}$ or nutrient availability with no information regarding soil buffering or nutrient release over time. Also, on-the-go mapping at a fixed depth may limit the ability to obtain representative measurements required for many prescription algorithms, especially in cases when soil stratification is pronounced. Multiple units operating at different depths could partially resolve this limitation for relatively shallow depth intervals, but may not be adequate for soil properties that require deep soil sampling (e.g., $\mathrm{NO}_{3}{ }^{-}$).

According to preliminary field trials, integrated, automated, on-the-go mapping of $\mathrm{pH}$, $\mathrm{K}^{+}$, and $\mathrm{NO}_{3}{ }^{-}$may be used to identify areas of fields with extremely low and high fertility levels and serve as a complimentary data layer for conventional soil sampling programs while significantly reducing the number of laboratory samples required.

To date, only those sensors equipped with ISEs or ISFETs are capable of direct measurement of soil chemical properties (Table 6). Unlike previously described measurement concepts, electrochemical sensors require a significant amount of time for the sensing element to reach equilibrium with the measured soil or soil solution. In addition, tedious sample preparation is needed if the principal steps of conventional laboratory chemical 
Table 6

Electrochemical sensors

\begin{tabular}{|c|c|c|c|}
\hline Sensor concept & Status of development & Current results & Key references \\
\hline $\begin{array}{l}\text { Ion-selective field effect } \\
\text { transistors (ISFETs) } \\
\text { with flow injection } \\
\text { analysis }\end{array}$ & Laboratory tests & $\begin{array}{l}\text { Correlation with nitrate } \\
\text { concentration in soil } \\
\text { extracts }\end{array}$ & $\begin{array}{l}\text { Birrell and Hummel } \\
(2001)\end{array}$ \\
\hline $\begin{array}{l}\text { Rapid extraction of soil } \\
\text { cores }\end{array}$ & Laboratory tests & $\begin{array}{l}\text { Potential for reducing } \\
\text { lag time between } \\
\text { sample collection and } \\
\text { sensor output }\end{array}$ & Price et al. (2003) \\
\hline $\begin{array}{l}\text { Electro-pneumatic } \\
\text { sampling method }\end{array}$ & Laboratory tests & $\begin{array}{l}\text { The method has } \\
\text { potential to be used } \\
\text { with PVC membrane } \\
\text { electrodes }\end{array}$ & Yildirim et al. (2003) \\
\hline $\begin{array}{l}\text { Core sampling wheel } \\
\text { with } \\
\text { indexing-processing } \\
\text { table }\end{array}$ & Soil bin and field tests & $\begin{array}{l}\text { Correlation with } \\
\text { conventional laboratory } \\
\text { electrode for nitrate } \\
\text { content and soil pH, } \\
\text { ISFETs were used }\end{array}$ & $\begin{array}{l}\text { Loreto and Morgan } \\
\text { (1996) }\end{array}$ \\
\hline $\begin{array}{l}\text { Sampling, conveying, } \\
\text { extracting and } \\
\text { measuring unit }\end{array}$ & $\begin{array}{l}\text { Laboratory and field } \\
\text { tests }\end{array}$ & $\begin{array}{l}\text { Correlation with nitrate } \\
\text { content, hardware } \\
\text { improvements were } \\
\text { required }\end{array}$ & Adsett et al. (1999) \\
\hline $\begin{array}{l}\text { Direct measurement of } \\
\text { ion activity using } \\
\text { ion-selective } \\
\text { electrodes }\end{array}$ & $\begin{array}{l}\text { Field tests and a } \\
\text { commercial implement }\end{array}$ & $\begin{array}{l}\text { Correlation with soluble } \\
\text { potassium, residual } \\
\text { nitrate content and } \mathrm{pH} \text {, } \\
\text { on-the-go mapping of } \\
\text { soil pH is available } \\
\text { commercially }\end{array}$ & $\begin{array}{l}\text { Adamchuk et al. (1999), } \\
\text { Adamchuk et al. } \\
\text { (2003a) }\end{array}$ \\
\hline
\end{tabular}

tests are replicated in a field sensing system. Sensor prototypes capable of accomplishing this task are relatively complex and still under development. Although the electrochemical measurements can be geo-referenced, the time lag between sample collection and sensor output precludes on-the-go control of variable rate lime and fertilizer applications.

Direct soil measurement is commercially available for mapping soil $\mathrm{pH}$. It is a much simpler concept but it does not provide real-time extraction of targeted ions, such as potassium. Therefore, the measurements represent "snapshots" of ion activity and current recommendations cannot be applied directly to prescribe variable rate lime and fertilizer applications. Alternatively, such recommendations can be developed if ion activity measurements are collocated with a soil buffering estimate (such as CEC) that can be predicted based on electrical conductivity and/or soil reflectance measurements.

\section{Conclusions}

Although various on-the-go soil sensors are under development, only electrical and electromagnetic sensors have been widely used in precision agriculture. Producers prefer sensors 
that provide direct inputs for existing prescription algorithms. Instead, commercially available sensors provide measurements, such as electrical resistivity/conductivity that cannot be used directly since the absolute value depends on a number of physical and chemical soil properties, such as texture, organic matter, salinity, moisture content, etc. In contrast, electrical and electromagnetic sensors give valuable information about soil differences and similarities which make it possible to divide the field into smaller and relatively homogeneous areas referred to as finite management elements (FMEs) or management zones. For example, such FME could be defined according to the various soil types found across a field. In fact, ER/EC maps usually reveal boundaries of certain soil types better than soil survey maps. Different anomalies such as eroded hillsides or ponding can also be easily identified on an ER/EC map. Yield maps also frequently correlate to ER/EC maps. In many instances such similarities can be explained through differences in soil. In general, the ER/EC maps may indicate areas where further exploration is needed to explain yield differences. Both yield potential and nutrient availability maps may have a similar pattern as soil texture and/or organic matter content maps. These patterns can often be revealed through an ER/EC map as well.

Therefore, it seems reasonable to use on-the-go mapping of electrical and electromagnetic soil properties as one layer of data to discover the heterogeneity (differences) of soil within a field. When based on multiple data layers, FMEs with similar electrical resistivity/conductivity and a relatively stable yield may receive a uniform treatment that can be prescribed based on a reduced number of soil samples located within each FME. Work done by Corvin and Lesch (2003) as well as by Heiniger et al. (2003) can serve as examples of site-specific data management that includes processing of EC maps. As new on-the-go soil sensors are developed, different real-time and map-based variable-rate soil treatments may be economically applied to much smaller field areas, subsequently reducing the effect of soil variability within each FME.

Integrating different measurement concepts in a single mapping unit is one of the current topics of research. It is believed that various sources of data fused together can better predict selected agronomic soil attributes and support site-specific crop management. An example of on-the-go soil sensors data fusion is coupling electrical conductivity with an optical sensor to determine the difference in organic matter, soil texture and moisture content in very diverse growing conditions. Another possibility is the use of an electrical conductivity map along with soil $\mathrm{pH}$ measurements to prescribe variable rate lime application. Studies investigating these and other data fusion approaches are currently active and more results should be available in the near future.

Another important issue with regard to the usefulness of on-the-go sensors is the economic value of the soil maps obtained. For example, data from electrical conductivity sensors were initially correlated to other soil properties. However, future research may show that EC data itself may be useful for making management decisions. In this case, the number of applications for the technology remain unknown until a reliable and widely accessible sensor can be used for field research across the globe. Therefore, it is anticipated that some of the reviewed sensor prototypes will be involved in agronomic and economic studies demonstrating the value and potential of information accessible through on-the-go soil sensors for precision agriculture. 


\section{Acknowledgements}

This publication is a contribution of the University of Nebraska Agricultural Research Division, Lincoln, NE, Journal Series No. 14275.

\section{References}

Adamchuk, V.I., Lund, E., Dobermann, A., Morgan, M.T., 2003a. On-the-go mapping of soil properties using ion-selective electrodes. In: Stafford, J., Werner, A. (Eds.), Precision Agriculture. Wageningen Academic Publishers, Wageningen, The Netherlands, pp. 27-33.

Adamchuk, V.I., Morgan, M.T., Ess, D.R., 1999. An automated sampling system for measuring soil pH. Transactions of the ASAE 42 (4), 885-891.

Adamchuk, V.I., Morgan, M.T., Lowenberg-DeBoer, J.M., 2004. A model for agro-economic analysis of soil pH mapping. Precision Agriculture 5, 109-127.

Adamchuk, V.I., Morgan, M.T., Sumali, H., 2001a. Application of a strain gauge array to estimate soil mechanical impedance on-the-go. Transactions of the ASAE 44 (6), 1377-1383.

Adamchuk, V.I., Morgan, M.T., Sumali, H., 2001b. Mapping of spatial and vertical variation of soil mechanical resistance using a linear pressure model. Paper No. 01-1019, ASAE, St. Joseph, Michigan.

Adamchuk, V.I., Skotnikov, A.V., Speichinger, J.D., Kocher, M.F., 2003b. Instrumentation system for variable depth tillage. Paper No. 03-1078, ASAE, St. Joseph, Michigan.

Adsett, J.F., Thottan, J.A., Sibley, K.J., 1999. Development of an automated on-the-go soil nitrate monitoring system. Applied Engineering in Agriculture 15 (4), 351-356.

Alihamsyah, T., Humphries, E.G., Bowers Jr., C.G., 1990. A technique for horizontal measurement of soil mechanical impedance. Transactions of the ASAE 33 (1), 73-77.

Andrade, P., Aguera, J., Upadhyaya, S.K., Jenkins, B.M., Rosa, U.A., Josiah, M., 2001a. Evaluation of a dielectric based moisture and salinity sensor for in-situ applications. Paper No. 01-1010, ASAE, St. Joseph, Michigan.

Andrade, P., Rosa, U.A., Upadhyaya, S.K., Jenkins, B.M., Aguera, J., Josiah, M., 2001b. Soil profile force measurements using an instrumented tine. Paper No. 01-1060, ASAE, St. Joseph, Michigan.

Andrade, P., Upadhyaya, S.K., Jenkins, B.M., Filho, A.G.S., 2002. Evaluation of UC Davis compaction profile sensor. Paper No. 02-1185, ASAE, St. Joseph, Michigan.

ASAE Standards, 49th ed., 2002. S313.2. Soil Cone Penetrometer. ASAE, St. Joseph, Michigan.

Baumgardner, M.F., Silva, L.F., Beihl, L.L., Stoner, E.R., 1985. Reflectance properties of soils. Advances in Agronomy 38, 1-44.

Birrell, S.J., Hummel, J.W., 1997. Multi-sensor ISFET system for soil analysis. In: Stafford, J.V. (Ed.), Proceedings of the First European Conference on Precision Agriculture. BIOS Scientific Publishers Ltd., Oxford, UK, pp. 459-468.

Birrell, S.J., Hummel, J.W., 2000. Membrane selection and ISFET configuration evaluation for soil nitrate sensing. Transactions of the ASAE 43 (2), 197-206.

Birrell, S.J., Hummel, J.W., 2001. Real-time multi-ISFET/FIA soil analysis system with automatic sample extraction. Computers and Electronics in Agriculture 32 (1), 45-67.

Buchleiter, G.W., Farahani, H., 2002. Comparison of electrical conductivity measurements from two different sensing technologies. Paper No. 02-1056, ASAE, St. Joseph, Michigan.

Christy, C., Drummond, P., Laird, D., 2003. An on-the-go spectral reflectance sensor for soil. Paper No. 03-1044, ASAE, St. Joseph, Michigan.

Chung, S., Sudduth, K.A., Hummel, J.W., 2003. On-the-go soil strength profile sensor using a load cell array. Paper No. 03-1071, ASAE, St. Joseph, Michigan.

Clement, B.R., Stombaugh, T.S., 2000. Continuously-measuring soil compaction sensor development. Paper No. 00-1041, ASAE, St. Joseph, Michigan.

Colburn, J.W., Jr., 1999. Soil Doctor multi-parameter, real-time soil sensor and concurrent input control system. In: Robert, P.C., Rust, R.H., Larson, W.E. (Eds.), Proceedings of the Fourth International Conference on Precision Agriculture. ASA-CSSA-SSSA, Madison, Wisconsin, pp. 1011-1021. 
Collins, K., Christy, C., Lund, E., Drummond, P., 2003. Developing an automated soil pH mapping system. Paper No. MC03-205, ASAE, St. Joseph, Michigan.

Corvin, D.L., Lesch, S.M., 2003. Application of soil electrical conductivity to precision agriculture: theory* principles* and guidelines. Agronomy Journal 95, 455-471.

Dabas, M., Tabbagh, A., 2003. A comparison of EMI and DC methods used in soil mapping-theoretical considerations for precision agriculture. In: Stafford, J., Werner, A. (Eds.), Precision Agriculture. Wageningen Academic Publishers, Wageningen, The Netherlands, pp. 121-127.

Davis, J.L., Annan, A.P., 2002. Ground penetrating radar to measure soil water content. In: Dane, J.H., Topp G.C. (Eds.), Methods of Soil Analysis, Part 4, Physical Methods. SSSA, Madison, Wisconsin, pp. 446-463.

Doolittle, J.A., Collins, M.E., 1995. Use of soil information to determine application of ground penetrating radar. Journal of Applied Geophysics 33 (1-3), 101-108.

Ehrhardt, J.P., Grisso, R.D., Kocher, M.F., Jasa, P.J., Schinstock, J.L., 2001. Using the Veris electrical conductivity cart as a draft predictor. Paper No. 01-1012, ASAE, St. Joseph, Michigan.

Ehsani, M.R., Upadhyaya, S.K., Slaughter, D., Protsailo, L.V., Fawcett, W.R., 2000. Quantitative measurement of soil nitrate content using mid-infrared diffuse reflectance spectroscopy. Paper No. 00-1046, ASAE, St. Joseph, Michigan.

Ehsani, M.R., Upadhyaya, S.K., Slaughter, D., Shafii, S., Pelletier, M., 1999. A NIR technique for rapid determination of soil mineral nitrogen. Precision Agriculture 1 (2), 217-234.

Fan, G., Zhang, N., Sun, Y., Oard, D., 2001. Simultaneous sensing of soil conductive and capacitive properties. Paper No. 01-1021, ASAE, St. Joseph, Michigan.

Foth, H.D., Ellis, B.G., 1988. Soil fertility. Wiley, New York, New York.

Frazier, B.E., Walters, C.S., Perry, E.M., Pierce, F.J., Sadler, E.J., 1997. Role of remote sensing in site-specific management. In: Pierce, F.T., Sadler, E.J. (Eds.), The State of Site-Specific Management for Agriculture. ASA-CSSA-SSSA, Madison, Wisconsin, pp. 149-160.

Freeland, R.S., Yoder, R.E., Ammons, J.T., 1998. Mapping shallow underground features that influence site-specific agricultural production. Journal of Applied Geophysics 40 (1), 19-27.

Freeland, R.S., Yoder, R.E., Ammons, J.T., Leonard, L.L., 2002. Integration of real-time global positioning with ground-penetrating radar surveys. Applied Engineering in Agriculture 18 (5), 647-650.

Fritz, R.M., Malo, D.D., Schumacher, T.E., Clay, D.E., Carlson, C.G., Ellsbury, M.M., Dalster, K.J., 1999. Field comparison of two soil electrical conductivity measurement systems. In: Robert, P.C., Rust, R.H., Larson, W.E. (Eds.), Proceedings of the Fourth International Conference on Precision Agriculture. ASA-CSSA-SSSA, Madison, Wisconsin, pp. 1211-1217.

Fystro, G., 2002. The prediction of $\mathrm{C}$ and $\mathrm{N}$ content and their potential mineralization in heterogeneous soil samples using Vis-NIR spectroscopy and comparative methods. Plant and Soil 246, 139-149.

Gelderman, R.H., Mallarino, A.P., 1998. Soil sample preparation. In: Brown, J.R. (Ed.), Recommended Chemical Soil Test Procedures for the North Central Region, North Central Regional Publication No., 221 (Revised), Chapter 1, pp. 5-6.

Glancey, J.L., Upadahyaya, S.K., Chancellor, W.J., Rumsey, J.W., 1989. An instrumented chisel for the study of soil-tillage dynamics. Soil and Tillage Research 14, 1-24.

Glancey, J.L., Upadahyaya, S.K., Chancellor, W.J., Rumsey, J.W., 1996. Prediction of agricultural implement draft using an instrumented analog tillage tool. Soil and Tillage Research 37, 47-65.

Havlin, J.L., Beaton, J.D., Tisdale, S.L., Nelson, W.L., 1999. Soil Fertility and Fertilizers. An Introduction to Nutrient Management. Sixth ed., Prentice Hall, Upper Saddle River, New Jersey.

Heiniger, R.W., McBride, R.G., Clay, D.E., 2003. Using soil electrical conductivity to improve nutrient management. Agronomy Journal 95, 508-519.

Hoeft, R.G., Peck, T.R., Boone, L.V., 1996. Soil testing and fertility. In: Illinois Agronomy Handbook 1995-1996, Circular 1333, Cooperative Extension Service, College of Agriculture, University of Illinois at Urbana-Champaign, Chapter 11, pp. 70-101.

Hummel, J.W., Gaultney, L.D., Sudduth, K.A., 1996. Soil property sensing for site-specific crop management. Computers and Electronics in Agriculture 14, 121-136.

Hummel, J.W., Sudduth, K.A., Hollinger, S.E., 2001. Soil moisture and organic matter prediction of surface and subsurface soils using an NIR soil sensor. Computers and Electronics in Agriculture 32 (2), 149-165.

Huisman, J.A., Hubbard, S.S., Redman, J.D., Annan, A.P., 2003. Measuring soil water content with ground penetrating radar: a review. Vadose Zone Journal 2, 476-491. 
Johnson, R.W., Glasscum, R., Wojtasinski, R., 1982. Application of ground penetrating radar to soil survey. Soil Survey Horizons 23 (3), 17-25.

Khalilian, A., Han, Y.J., Dodd, R.B., Sullivan, M.J., Gorucu, S., Keskin, M., 2002. A Control System for Variable Depth Tillage. Paper No. 02-1209, ASAE, St. Joseph, Michigan.

Krishnan, P., Alexander, J.D., Butler, B.J., Hummel, J.W., 1980. Reflectance technique for predicting soil organic matter. Soil Sci. Soc. Am. J. 44, 1282-1285.

Lee, K.H., Zhang, N., Fan, G., Kluitenberg, G., Loughin, T., 2002. Simultaneous Measurement of Soil Water Content and Salinity at Controlled Density and Depth. Paper No. 02-1095, ASAE, St. Joseph, Michigan.

Lee, W.S., Mylavarapu, R.S., Choe, J.S., Whitney, J.D., 2001. Study on soil properties and spectral characteristics in Florida. Paper No. 01-1179, ASAE, St. Joseph, Michigan.

Liu, W., Gaultney, L.D., Morgan, M.T., 1993. Soil Texture Detection Using Acoustic Methods. Paper No. 93-1015, ASAE, St. Joseph, Michigan.

Liu, W., Upadahyaya, S.K., Kataoka, T., Shibusawa, S., 1996. Development of a texture/soil compaction sensor. In: Robert, P.C., Rust, R.H., Larson, W.E. (Eds.), Proceedings of the Third International Conference on Precision Agriculture. ASA-CSSA-SSSA, Madison, Wisconsin, pp. 617-630.

Loreto, A.B., Morgan, M.T., 1996. Development of an Automated System for Field Measurement of Soil Nitrate. Paper No. 96-1087, ASAE, St. Joseph, Michigan.

Lund, E.D., Colin, P.E., Christy, D., Drummond, P.E., 1999. Applying soil electrical conductivity technology to precision agriculture. In: Robert, P.C., Rust, R.H., Larson, W.E. (Eds.), Proceedings of the Fourth International Conference on Precision Agriculture. ASA-CSSA-SSSA, Madison, Wisconsin, pp. 1089-1100.

Manor, G., Clark, R.L., 2001. Development of An Instrumented Subsoiler to Map Soil Hard-Pans and Real-Time Control of Subsoiler Depth. Paper No. 01-1022, ASAE, St. Joseph, Michigan.

Morgan, M.T., Ess, D.R., 1997. The Precision-Farming Guide for Agriculturists. An agriculture primer. John Deere Publishing, Moline, IL.

Mueller, T.G., Hartsock, N.J., Stombaugh, T.S., Shearer, S.A., Cornelius, P.L., Barnhisel, R.I., 2003. Soil electrical conductivity map variability in limestone soils overlain by loess. Agronomy Journal 96, 496-507.

Odhiambo, L.O., Freeland, R.S., Yoder, R.E., Hines, J.W., 2002. Application of fuzzy-neural network in classification of soils using ground-penetrating radar imagery. Paper No. 02-3097, ASAE, St. Joseph, Michigan.

Owen, G.T., Drummond, H., Cobb, L., Godwin, R.J., 1987. An instrumentation system for deep tillage research. Transactions of the ASAE 30 (6), 1578-1582.

Pierce, F.J., Nowak, P., 1999. Aspects of precision agriculture. Adv. Agronomy 67, 1-85.

Price, R.R., Hummel, J.W., Birrell, S.J., Ahmad, I.S., 2003. Rapid nitrate analysis of soil cores using ISFETs. Transactions of the ASAE 46 (3), 601-610.

Raper, R.L., Hall, E.H., 2003. Soil strength measurement for site-specific agriculture. US Patent No. 6647799, US Patent and Trademark Office, Washington, DC.

Reeves III, J.B., McCarty, G.W., Mimmo, T., 2002. The potential of diffuse reflectance spectroscopy for the determination of carbon inventories in soils. Environment Pollution 116, S277-S284.

Shibusawa, S., I Made Anom, S.W., Hache, C., Sasao, A., Hirako, S., 2003. Site-specific crop response to temporal trend of soil variability determined by the real-time soil spectrophotometer. In: Stafford, J., Werner, A. (Eds.), Precision Agriculture. Wageningen Academic Publishers, Wageningen, The Netherlands, pp. 639-643.

Shibusawa, S., Li, M.Z., Sakai, K., Sasao, A., Sato, H., Hirako, S., Otomo, A., 1999. Spectrophotometer for Real-Time Underground Soil Sensing. Paper No. 99-3030, ASAE, St. Joseph, Michigan.

Shonk, J.L., Gaultney, L.D., Schulze, D.G., Van Scoyoc, G.E., 1991. Spectroscopic sensing of soil organic matter content. Transactions of the ASAE 34 (5), 1978-1984.

Sonka, S.T., Bauer, M.E., Cherry, E.T., Colburn, J.W., Heimlich, R.E., Joseph, D.A., Leboeuf, J.B., Lichtenberg, E., Mortensen, D.A., Searcy, S.W., Ustin, S.L., Ventura, S.J., 1997. Precision agriculture in the 21st century. Geospatial and information technologies in crop management. Committee on Assessing Crop Yield: Site-Specific Farming, Information Systems, and Research Opportunities, Board of Agriculture, National Research Council. National Academy Press, Washington, DC.

Stafford, J.V., Hendrick, J.G., 1988. Dynamic sensing of soil pans. Transactions of the ASAE 31 (1), 9-13.

Starr, J.L., Paltineanu, I.C., 2002. Capacitance Devices. In: Dane, J.H., Topp, G.C. (Eds.), Methods of Soil Analysis, Part 4, Physical Methods. SSSA, Madison, Wisconsin, pp. 463-474.

Stoner, E.R., Baumgardner, F., 1981. Characteristic variations in reflectance of surface soils. Journal of Soil Science Society of America 45, 1161-1165. 
Sudduth, K.A., Drummond, S.T., Kitchen, N.R., 2001. Accuracy issues in electromagnetic induction sensing of soil electrical conductivity for precision agriculture. Computers and Electronics in Agriculture 31, $239-264$.

Sudduth, K.A., Hummel, J.W., 1993a. Portable near infrared spectrophotometer for rapid soil analysis. Transactions of the ASAE 36 (1), 185-193.

Sudduth, K.A., Hummel, J.W., 1993b. Soil organic matter, CEC, and moisture sensing with a portable NIR spectrophotometer. Transactions of the ASAE 36 (6), 1571-1582.

Sudduth, K.A., Hummel, J.W., 1996. Geographic operating range evaluation of an NIR soil sensor. Transactions of the ASAE 39 (5), 1599-1604.

Sudduth, K.A., Hummel, J.W., Birrell, S.J., 1997. Sensors for site-specific management. In: Pierce, F.T., Sadler, E.J. (Eds.), The State of Site-Specific Management for Agriculture, ASA-CSSA-SSSA, Madison, Wisconsin, Chapter 10, pp. 183-210.

Sudduth, K.A., Kitchen, N.R., Bollero, G.A., Bullock, D.G., Wiebold, W.J., 2003. Comparison of electromagnetic induction and direct sensing of soil electrical conductivity. Agronomy Journal 95, 472-482.

Tekeste, M.Z., Grift, T.E., Raper, R.L., 2002. Acoustic Compaction Layer Detection. Paper No. 02-1089, ASAE, St. Joseph, Michigan.

Truman, C.C., Perkins, H.F., Asmussen, L.E., Allison, H.D., 1988. Using ground penetrating radar to investigate variability in selected soil properties. Journal of Soil and Water Conservation 43 (4), 341-345.

Upadhyaya, S.K., Rosa, U.A., Ehsani, M., Koller, M., Josiah, M., Shikanai, T., 1999. Precision Farming in a Tomato Production System. Paper No. 99-1147, ASAE, St. Joseph, Michigan.

Upadhyaya, S.K., Shafii, S., Chancellor, W.C., 1993. Determination of Soil Nitrogen Content In Situ: A Literature Review. Report submitted to the Fertilizer Research and Education Program (FREP), California Department of Food and Agriculture, Sacramento, California.

Van Bergeijk, J., Goense, D., 1996. Soil tillage resistance as tool to map soil type differences. In: Robert, P.C., Rust, R.H., Larson, W.E. (Eds.), Proceedings of the Third International Conference on Precision Agriculture, ASA-CSSA-SSSA, Madison, Wisconsin, pp. 605-616.

Vaughan, B., 1999. How to determine an accurate soil testing laboratory. In: Clay et al. (Ed.) Site Specific Management Guidelines SSMG 4. Potash and Phosphate Institute, Norcross, Georgia.

Verschoore, R., Pieters, J.G., Seps, T., Spriet, Y., Vangeyte, J., 2003. Development of a sensor for continuous soil resistance measurement. In: Stafford, J., Werner, A. (Eds.), Precision Agriculture. Wageningen Academic Publishers, Wageningen, The Netherlands, pp. 689-695.

Viscarra Rossel, R.A., McBratney, A.B., 1998. Laboratory evaluation of a proximal sensing technique for simultaneous measurement of clay and water content. Geoderma 85, 19-39.

Vitosh, M.L., Johnson, J.W., Mengel, D.B., 1995. Tri-state fertilizer recommendations for corn, soybeans, wheat and alfalfa. Extension Bulletin E-2567. Michigan State University, The Ohio State University, and Purdue University.

Whalley, W.R., Bull, C.R., 1991. An assessment of microwave reflectance as a technique for estimating the volumetric water content of soil. Journal of Agricultural Engineering Research 50, 315-326.

Whalley, W.R., Dean, T.J., Izzard, P., 1992. Evaluation of the capacitance technique as a method for dynamically measuring soil water content. Journal of Agricultural Engineering Research 52, 147-155.

Wollenhaupt, N.C., Mulla, D.J., Gotway Crawford, C.A., 1997. Soil sampling and interpolation techniques for mapping spatial variability of soil properties. In: Pierce, F.T., Sadler, E.J. (Eds.), The State of Site-Specific Management for Agriculture, ASA-CSSA-SSSA, Madison, Wisconsin, Chapter 2, pp. 19-53.

Wood, R.K., Morgan, M.T., Holmes, R.G., Brodbeck, K.N., Carpenter, T.G., Reeder, R.C., 1991. Soil physical properties as affected by traffic: singles* dual* and floatation tires. Transactions of the ASAE 34 (6), 2363 2369.

Yildirim, S., Birrell, S.J., Hummel, J.W., 2003. Laboratory evaluation of an electro-pneumatic sampling method for real-time soil sensing. Transactions of the ASAE, in press. 